\title{
Study on Properties of Glazed Tiles Heated by the Low-Carbon Catalytic Combustion Furnace of Natural Gas
}

\author{
Ran Li, Fangjing Jia, Shihong Zhang, Suilin Wang \\ Beijing Key Lab of Heating, Gas Supply, Ventilating and Air Conditioning Engineering, \\ Beijing University of Civil Engineering and Architecture, Beijing, China \\ Email: 457698268@qq.com, 250889525@qq.com, shihongzhang@bucea.edu.cn, suilinwang@bucea.edu.cn
}

Received 25 July 2016; accepted 8 August 2016; published 15 August 2016

\begin{abstract}
This experiment aims to summarize the properties of glazed tiles that heated by the low-carbon catalytic combustion furnace of natural gas. The tiles heated by the catalytic combustion furnace are more fine and glossy than the conventional ones. This conclusion provides a new way to glazed tile heating industry. Only with a better understanding of catalytic combustion, can the application benefit our environment and industry.
\end{abstract}

\section{Keywords}

\section{Glazed Tile Heating, Catalytic Combustion}

\section{Introduction}

Brilliant and lustrous glazed tiles usually with yellow, green, and blue glaze are Chinese traditional architectural objects. Due to their solid material and bright colors, glazed tiles have been the proud of the building ceramics. China has a long history of using glazed tiles as decoration, as early as the Northern and Southern Dynasties to the Yuan Dynasty whose palace buildings used a large-scale of glazed tiles. Ming Tombs, the Forbidden City and the Nine Dragon Wall are all masterpieces in glazed tile construction history.

Now the glazed tiles used on those ancient buildings are seriously damaged so that repairing work requires a lot of tile pieces. Take this opportunity, we hope that the low-carbon catalytic combustion furnace can provide tiles of similar quality and at the same time, glazed tiles manufacturing of low pollution and low emission production may be provided.

The traditional tiles are heated in the environment of 850 to 1000 degrees Celsius. We follow the ancient laws, putting the glazed tiles which are heated in the environment of 1050 to 1200 degrees Celsius under an unglazed condition into the low-carbon catalytic combustion furnace for secondary heating. In order to ensure the temperature to rise regularly, we have to repeatedly adjust the door opening and air, gas quantity. After many times of attempts, we have obtained the beautiful glazed tile products.

Based on these aspects, the effect of low-carbon catalytic combustion tile heating cannot be ignored. Originated from the United Kingdom, lean natural gas-air mixtures using in the combustion catalytic combustion was 
brought to China and gradually developed into what it is now. In theory, when the temperature in a furnace is about 1200 degrees Celsius, catalytic combustion of heterogeneous catalysis discharges a very small amount of $\mathrm{CO}$, nitrogen oxides and unburned hydrocarbons [1]. With the technology, we can produce tiles without fire so that the tiles can be more fine and glossy than the conventional ones.

\section{Experimental Set-Up}

Figure 1 presents the conventional diagram about system of catalytic combustion burner. Look at the experimental set-up from the left, the flue gas analyzer is the first one. Beside the flue gas analyzer is the catalytic burner. The furnace body is connected to the catalytic combustion of burner which is installed two square catalytic honeycomb monolith every time .Every square honeycomb monoliths was $150 \mathrm{~mm}$ wide in sides of the square and $20 \mathrm{~mm}$ long, with square-shaped cells whose sectional area was $1 \mathrm{~mm} \times 1 \mathrm{~mm}$. The reaction region inside the catalysts was ended at about $10 \mathrm{~mm}$ from the monolith's entrance. The right part of burner connected with a section of pipe, which is a mixture of air and gas [2].

In order to control the flow rate of natural gas and air, CMS0050BSRN200000 natural gas meter and CMG400A080100000 air meter with $0-50 \mathrm{~L} / \mathrm{min}$ and $0-80 \mathrm{~m}^{3} / \mathrm{h}$ of full-scale range, which get electric from manostat to operate were equipped [3]. The two meters were provided electric current. Exhaust gas went into the flue gas analyzer through a hole on the left side of the burner.

Put a tile embryo on the pallet and let it spin. When the temperature was relatively stable, the air is firstly let in gas volume to $3.7 \mathrm{~m}^{3} / \mathrm{h}$ and the nature gas is put onto the level of $5.0 \mathrm{~L} / \mathrm{min}$, and then the furnace starts running at the same time. Record the data every five minutes. After a few minutes, confirm the furnace is operating normally. The data includes temperature, concentration of carbon dioxide, carbon monoxide, nitric oxide, nitrogen oxide and methane. Initially, the door of the heating furnace was fully opened, in order to keep the temperature not too high [4]. At the beginning there was flame inside. When the flame extinguished and the catalytic combustion began, put the air degree into $5.7 \mathrm{~m}^{3} / \mathrm{h}$. The moment the temperature was relatively stable again, the door was shut gradually to $15 \mathrm{~cm}$ between door and doorjamb. The subsequent experiment process was the same taking the distance between door and doorjamb to $10 \mathrm{~cm}, 7 \mathrm{~cm}$ and $4 \mathrm{~cm}$, then the door was completely closed. And after the door's closing, the volumes of natural gas were adjusted into 6, 7, 7.5, $8 \mathrm{~L} / \mathrm{min}$, at the same time, adjust the air into $6.8,8.0,8.4,8.9 \mathrm{~m}^{3} / \mathrm{h}$. When the temperature rose to 800 degrees Celsius, continued heating the tile until the temperature approach 900 degrees Celsius. Then closed the nature gas and put the air to 5.7 $\mathrm{m}^{3} / \mathrm{h}$ for a while before the end.

\section{Result and Discussion}

\section{The Variation of Exhaust Gas Constituent}

Figure 2 shows the concentration of carbon dioxide. Carbon dioxide was the most stable gas whose concentration changed regularly. Before closing the door, the concentration of carbon dioxide was the same with that in the air. When the door was closed, its concentration increased rapidly, until occupied $5 \%-6 \%$ of the total gas, then this value was fluctuating around. The value should be the one that the environment inside catalytic combustion burner reached stable.

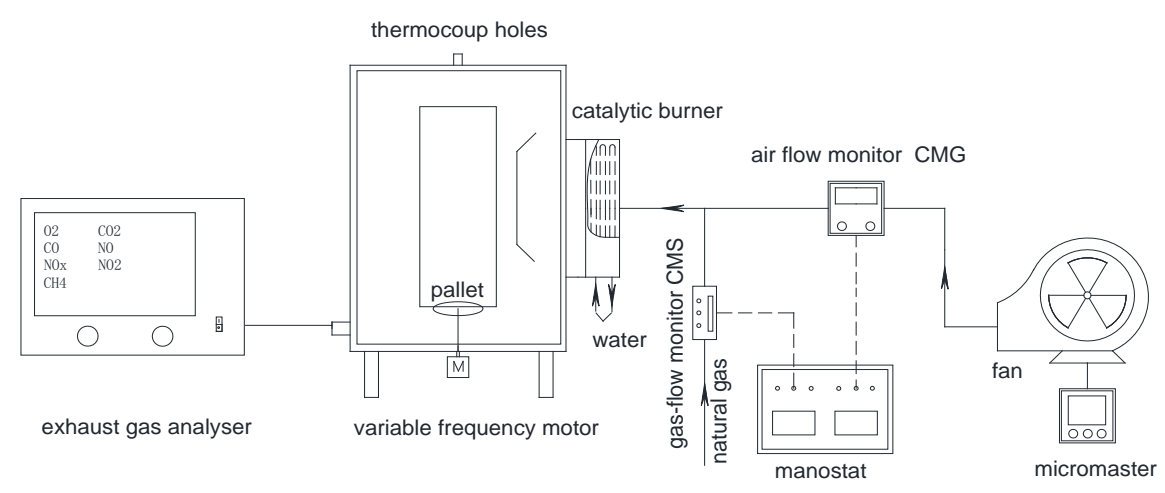

Figure 1. Combustion system of catalytic combustion burner. 


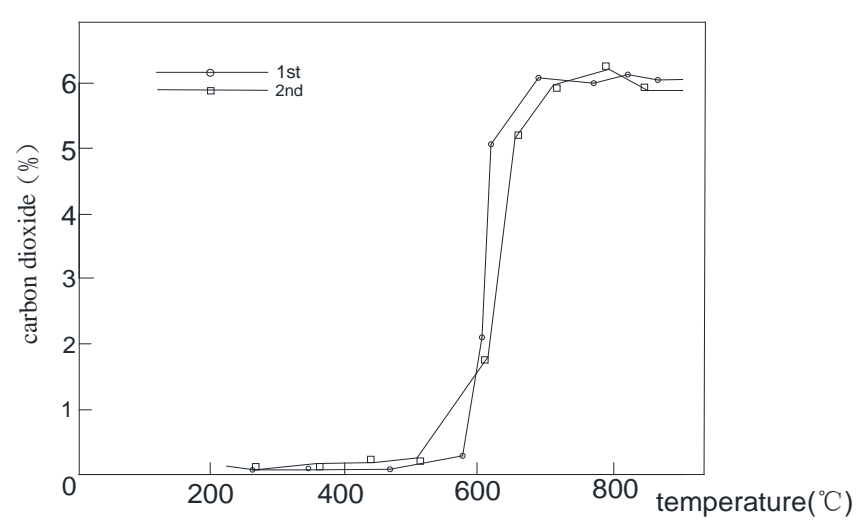

Figure 2. The concentration of carbon dioxide.

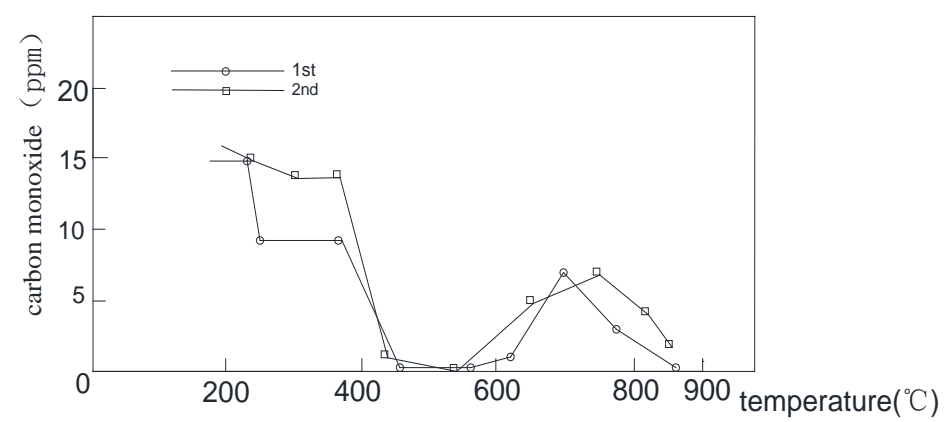

Figure 3. The concentration of carbon monoxide.

Figure 3 shows the concentration of carbon monoxide. In the process of heating glazed tile, the tile bodies released part of carbon monoxide, which caused a sudden rise of carbon monoxide after closing the door. From the figure we can see that different glazed tile released different amount of $\mathrm{CO}_{2}$, maybe because every tile's size is not the same every time. Until the furnace temperature reached 900 degrees and the heating basically completed, the tiles no longer release carbon monoxide. So the carbon monoxide concentration inside the furnace gradually stabilized.

Figure 4 shows the concentration of nitrogen oxide. According to the picture, the concentration of nitrogen oxide at the beginning was unstable. When the temperature raised to about four to seven hundred degrees Celsius, the concentration of nitrogen oxide gradually decreased until zero. Due to the differences of each burner, and the differences in experimental operation, every nitrogen oxide concentration's peak value and stable value are different. We infer that the reason is that the concentration of nitrogen oxide not only depends on temperature, but also depends on the environment inside the burner after closing the door. What's more, burning with flame at the beginning produced NO, but the environment inside the catalytic combustion burner gradually turned towards stability, which makes the nitrogen oxide concentration declined.

\section{Products Exhibition}

Figure 5 and Figure 6 are the final products that heated by the low-carbon catalytic combustion furnace.

\section{Conclusions}

Overall, the glazed tiles heated by the catalytic combustion furnace possess more excellent color with very even texture. Under the sunshine, the glazed tiles are glittering and brilliant. If you have a closer look, low-carbon catalytic combustion furnace provides tiles with more delicate texture, also have a fresh and transparent glaze. Moreover, these tiles are very smooth to touch, and at the same time they create a strong artistic atmosphere.

Traditionally, tiles have to be heated twice and the whole process takes 11 days. Furnaces burning coal and oil produce a huge quantity of smoke-pollution including $\mathrm{SO}_{2}, \mathrm{NO}_{\mathrm{X}}$ and $\mathrm{CO}$. So it's obviously that traditional me- 


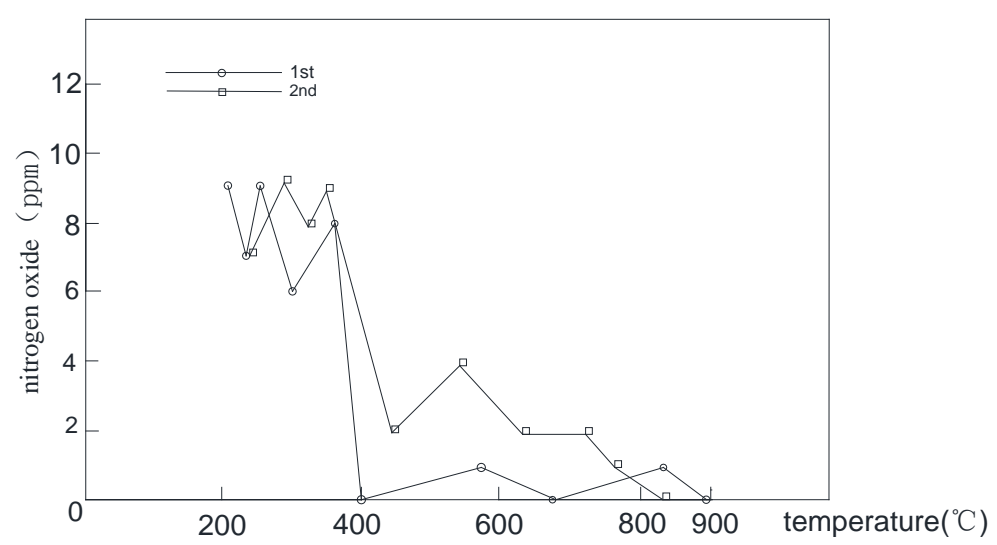

Figure 4. The concentration of nitrogen oxide.

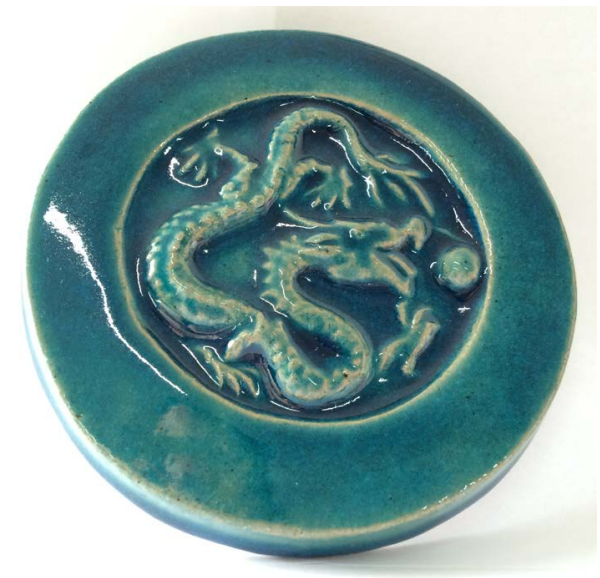

Figure 5. Finished product-1.

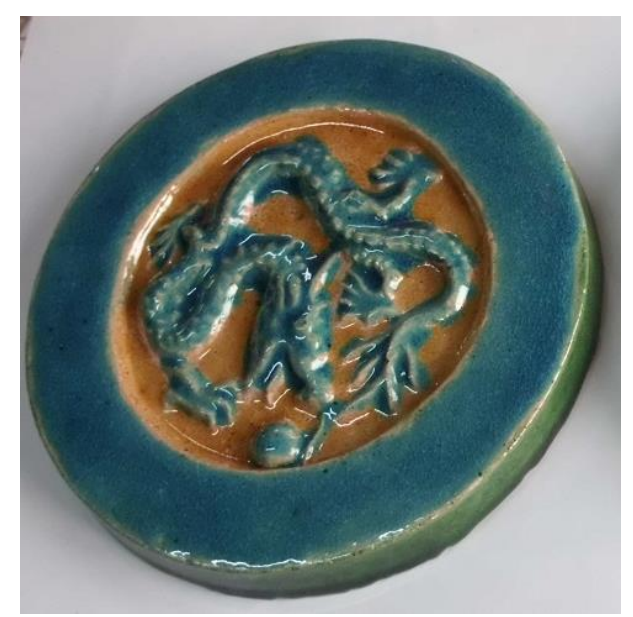

Figure6. Finished procuct-2.

thods to fire tiles cost a lot of time and cause serious environmental pollution. However, we can easily find that heating tiles with the technology of low-carbon catalytic combustion furnace of natural gas almost completely avoids sulfide production, while emissions of $\mathrm{NO}_{\mathrm{x}}$ and $\mathrm{CO}$ reduced greatly. Moreover, the natural gas catalytic combustion technology greatly suppresses the $\mathrm{N}_{2}$ becoming $\mathrm{NO}_{\mathrm{x}}$ for its low reaction temperature, so the impact on the environment can be much smaller comparing to traditional industry. 


\section{Acknowledgements}

The project was sponsored by the Beijing Municipality Key Lab of Heating, Gas Supply, Ventilating and Air Conditioning Engineering and Collaborative Innovation Center of Key Technologies of Energy Saving and Emission Reduction; Science and Technology Innovation Ability Promoting Project of Beijing Municipal Commission of Education (PXM2016_014210_000016).

\section{References}

[1] Zhang, S.H., Valerie, D., Alan, W. and Gavin, R. (2010) Mechanisms and Applications of Catalytic Combustion of Natural Gas in the Presence of Sulphur Compounds. The Science Press, Beijing, 56-88.

[2] Wang, X.Y., Zhu, L.Q. and Zhang, S.H. (2013) Study on Low-Carbon Catalytic Combustion Furnace of Natural Gas and the Application in Greenhouse. Advanced Materials Research, 788, 298-301. http://dx.doi.org/10.4028/www.scientific.net/AMR.788.298

[3] Reng, B.Y., Zhu, L.Q. and Zhang, S.H. Instance of Practical Engineering Application for Professional Education.

[4] Li, R., Fang, K. and Zhang, S.H. Research on the Application in Glazed Tile Heating of the Low-carbon Catalytic Combustion Furnace of Natural Gas.

\section{Submit or recommend next manuscript to SCIRP and we will provide best service for you:}

Accepting pre-submission inquiries through Email, Facebook, LinkedIn, Twitter, etc.

A wide selection of journals (inclusive of 9 subjects, more than 200 journals)

Providing 24-hour high-quality service

User-friendly online submission system

Fair and swift peer-review system

Efficient typesetting and proofreading procedure

Display of the result of downloads and visits, as well as the number of cited articles

Maximum dissemination of your research work

Submit your manuscript at: http://papersubmission.scirp.org/ 